\title{
Extracellular Matrix and Integrin Expression Profiles in Fuchs Endothelial Corneal Dystrophy Cells and Tissue Model
}

\author{
Benjamin Goyer, MSc, ${ }^{1,2, *}$ Mathieu Thériault, MSc, ${ }^{1,2, *}$ Sébastien P. Gendron, PhD,,2 \\ Isabelle Brunette, MD, FRCSC, ${ }^{3,4}$ Patrick J. Rochette, $\mathrm{PhD}^{1,2,5}$ and Stéphanie Proulx, $\mathrm{PhD}^{1,2,5}$
}

Primary corneal endothelial cell (CEC) cultures and 3D-engineered tissue models were used to study the aberrant deposition of extracellular matrix (ECM) in a vision impairing pathology known as Fuchs endothelial corneal dystrophy (FECD). CECs were isolated from excised Descemet membranes of patients with end-stage FECD. CECs isolated from healthy corneas served as controls. Microarray gene profiling was performed on postconfluent cultures of healthy and FECD cells. Protein expression analyses were conducted on tissue models that were engineered by seeding an endothelium on previously devitalized human stromal carriers. The engineered endothelia were kept in culture for 1-3 weeks to reform the endothelial monolayer. Protein expression of integrin subunits $\alpha 4, \alpha 6, \alpha v$, and $\beta 1$, as well as laminin, type IV collagen, fibronectin, clusterin, and transforming growth factor $\beta$-induced protein (TGF $\beta$ Ip) was then assessed by immunofluorescence. Microarray analysis showed nonstatistical twofold downregulation of collagen-coding genes (COL4A4, COL8A2, and COL21A1) and a twofold upregulation of the COL6A1, laminin $\alpha 3$ gene LAMA3, and integrin subunit $\alpha 10$ gene ITGA10 in FECD cells. Fibronectin type III domain containing 4 (FNDC4) and integrin $\beta 5$ (ITGB5) genes was significantly upregulated in FECD cells. Immunostainings demonstrated that the protein expression of the integrin subunits $\alpha 4, \alpha 6, \alpha \mathrm{v}$, and $\beta 1$, type IV collagen, as well as laminin remained similar between native and engineered endothelia. TGF $\beta I p$ expression was found on the stromal side of both FECD and healthy Descemet's membrane, and only one out of three FECD specimens was positive for the clusterin protein. Interestingly, the ECM protein fibronectin was also found to have a stronger presence on engineered FECD tissues, a result consistent with the native FECD specimens. To conclude, this study allowed to identify fibronectin deposition as one of the first steps in the pathogenesis of FECD, as defined by our engineered tissue model. This opens the way to an entirely new perspective for in vitro pharmacological testing of new therapies for FECD, the leading indication for corneal transplantation in North America.

Keywords: corneal endothelium, Fuchs corneal endothelial dystrophy, cell culture, tissue engineering, gene profiling, immunolocalization, extracellular matrix, integrins, fibronectin

\section{Introduction}

$\mathbf{T}$ HE CORNEA Is the transparent tissue located in the front part of the eye. It is layered on its posterior surface by the corneal endothelium, which consists of a monolayer of confluent flattened cells responsible for maintaining corneal transparency by ensuring constant stromal dehydration. Corneal endothelial cell (CEC) dysfunction results in corneal edema, loss of corneal transparency, and irreversible blindness. ${ }^{1}$ Fuchs endothelial corneal dystrophy (FECD) is a slowly progressive corneal disease that becomes clinically evident in adults aged over 40. In 2015, FECD was

\footnotetext{
${ }^{1}$ Centre de Recherche du CHU de Québec-Université Laval, Axe Médecine Régénératrice, Hôpital du Saint-Sacrement, Québec, Canada.

${ }^{2}$ Centre de Recherche en Organogénèse Expérimentale de l'Université Laval/LOEX, Québec, Canada.

${ }^{3}$ Centre Universitaire d'Ophtalmologie de l'Université de Montréal et Centre de Recherche de l'Hôpital Maisonneuve-Rosemont, CIUSSS-E, Montréal, Canada.

${ }^{4}$ Hôpital Maisonneuve-Rosemont Research Center, CIUSSS-E, Montréal, Canada.

${ }^{5}$ Département d'Ophtalmologie et d'Oto-Rhino-Laryngologie-Chirurgie Cervico-Faciale, Faculté de Médecine, Université Laval, Québec, Canada.

*These authors contributed equally to this work.

(C) Benjamin Goyer et al. 2018; Published by Mary Ann Liebert, Inc. This Open Access article is distributed under the terms of the Creative Commons Attribution Noncommercial License (http://creativecommons.org/licenses/by-nc/4.0/) which permits any noncommercial use, distribution, and reproduction in any medium, provided the original author(s) and the source are cited.
} 
responsible for $15707(21.7 \%)$ of the 72465 corneal transplantations performed in the United States. ${ }^{2}$ There are currently no treatments for FECD other than corneal transplantation.

CECs secrete and deposit extracellular matrix (ECM) proteins that form a specialized basement membrane called Descemet's membrane (DM). A normal DM contains collagen type VIII, collagen type IV (chains $\alpha 1-\alpha 2$ ), and fibronectin on its stromal side and entactin, laminin, perlecan, and collagen type IV (chains $\alpha 3-\alpha 6$ ) on its endothelial side. ${ }^{3,4} \mathrm{DM}$ is composed of two layers, an anterior banded layer (fetal layer) of $\sim 3 \mu \mathrm{m}$ thickness that remains relatively constant after formation in utero, and a posterior nonbanded layer (postnatal) that is continuously produced during life. Its thickness reaches $\sim 10 \mu \mathrm{m}$ at age $80 .^{5}$

The main feature of FECD is its irregular DM, which can be up to four times thicker than normal. ${ }^{6-8}$ The anterior banded layer is normal, however, the posterior nonbanded layer is either absent or very thin. It is replaced by an abnormal collagenous banded layer that typically contains focal excrescences called guttae. In some cases, a loose fibrillar layer also embeds the guttae. ${ }^{6-11}$ Previous reports showed an increased expression of collagen type IV, laminin, and fibronectin at the posterior side of the DM. ${ }^{12-14}$ The glycoprotein clusterin and transforming growth factor $\beta$-induced protein (TGF $\beta$ Ip) have also been shown to be elevated in FECD and to colocalize at the guttae. ${ }^{14-16}$ A recent study also reported an overexpression of the ECM proteins agrin, collagen type III, and collagen type $\mathrm{XVI}$ in the posterior collagenous layer of DM of FECD specimens. ${ }^{14}$

Integrins form a family of transmembrane glycoproteins that regulate cell-cell and cell-ECM interactions ${ }^{17,18}$ They control many cellular processes, including adhesion, migration, proliferation, survival, and differentiation. ${ }^{19,20}$ Integrins are heterodimeric molecules composed of an $\alpha$ subunit, that confers most of the ECM ligand specificity, and a $\beta$ subunit, that interacts with the intracellular cytoskeleton via adaptor proteins and determines the broad class of the receptor. ${ }^{21,22}$ Eight $\beta$ - and $18 \alpha$ - subunits have been identified, that can associate with each other to produce the 24 integrin heterodimers reported to date. ${ }^{23-2}$ Cultured healthy CECs were shown to express ITGA1, ITGA2, ITGA3, ITGAV, ITGB1, ITGB3, and ITGB5 genes, ${ }^{28}$ while native FECD endothelial cells were shown to upregulate ITGA1, ITGA3, ITGA4, ITGAL, ITGB1, ITGB3, and ITGB4 genes. ${ }^{14}$ To our knowledge, there has been no report on the integrin protein expression profile of the corneal endothelium, neither healthy nor diseased.

Reports on gene and protein expression in FECD describe the pathology at the end stage of the disease, since the specimens are obtained at the time of corneal transplantation or from postmortem tissues. ${ }^{14,29-31}$ Knowing that DM thickening is the first clinical sign of the disease, ${ }^{32}$ a better understanding of early ECM protein deposition could shed light on the pathogenesis of FECD. Recent advances in corneal tissue engineering bring us a unique opportunity to study early ECM deposition by FECD cells. Our group has reported on the successful culture of both normal ${ }^{33,34}$ and FECD CECs. ${ }^{11}$ We have used these cultured cells to engineer a corneal endothelium shown to be functional 1 week after transplantation in a living animal eye. ${ }^{35-37}$ We now propose to use these novel engineered tissues to examine the
ECM protein deposition by the FECD cells and to characterize the integrin subunits that link these cells to a healthy DM. Understanding the aberrant deposition of ECM by the FECD cells may help to elucidate some of the aspects of FECD pathogenesis and lead to the development of new therapeutic approaches aimed at preventing abnormal ECM deposition and subsequent loss of endothelial cell functionality in this disease.

\section{Materials and Methods}

\section{Biological material}

This study was conducted according to our institutions' guidelines and the Declaration of Helsinki. Eighteen DM with attached endothelium were harvested from 18 consenting patients with end-stage clinical FECD at the time of their corneal transplantation ${ }^{11}$ and were randomly assigned to one of the following groups. Six specimens were used for cell culture and gene expression profiling by microarray (age range: $58-82$ years, mean \pm standard deviation [SD]: $69 \pm 10$ years). Seven specimens were used to engineer corneal endothelia (age range: $58-77$ years, mean \pm SD: $67 \pm 8$ years). Five specimens were used for the immunostaining experiments (age range: $57-82$ years, mean \pm SD: $67 \pm 10$ ).

Native human corneas without endothelial diseases (healthy) and unsuitable for transplantation in human subjects were obtained from our local eye bank (Banque d'Yeux du Centre universitaire d'ophtalmologie [CUO], Québec, QC, Canada). These healthy corneas were used for cell culture and gene expression profiling by microarray (six corneas; age range: $58-82$ years, mean $\pm S D: 71 \pm 10$ years), for the engineering of healthy corneal endothelia (two corneas; aged 47 and 68 years), as carriers for the engineered corneal endothelia (10 corneas; age range: 54-84 years, mean \pm SD: $69 \pm 10$ years) and for the immunostaining experiments (seven corneas; range: $68-84$ years, mean \pm SD: $74 \pm 12$ ).

\section{Isolation and culture of CECs from healthy and FECD corneas}

All CECs were isolated as described previously. ${ }^{38}$ In brief, DM were peeled off and incubated overnight in growth medium at $37^{\circ} \mathrm{C}$. After centrifugation, they were incubated $1 \mathrm{~h}$ in $0.02 \%$ ethylenediaminetetraacetic acid (Sigma, Oakville, ON, Canada), and the loosened cells were detached from the DM by passing several times through a flamed-polished pipet. Cells were then centrifuged and resuspended in fresh medium consisting of OptiMem-I (Invitrogen, Burlington, ON, Canada), 8\% fetal bovine serum (HyClone, Logan, UT), $5 \mathrm{ng} /$ $\mathrm{mL}$ human epidermal growth factor (Austral Biologicals, San Ramon, CA), $20 \mathrm{ng} / \mathrm{mL}$ nerve growth factor (Biomedical Technologies, Stoughton, MA), $100 \mu \mathrm{g} / \mathrm{mL}$ bovine pituitary extract (Biomedical Technologies), $20 \mu \mathrm{g} / \mathrm{mL}$ ascorbic acid (Sigma), 0.08\% chondroitin sulfate (Sigma), $25 \mu \mathrm{g} / \mathrm{mL}$ gentamicin sulfate (Scheringm Pointe Claire, QC, Canada), and $100 \mathrm{IU} / \mathrm{mL}$ penicillin $\mathrm{G}$ (Sigma). Cells were plated on dishes covered with a fibronectin, collagen, and albumin coating mix (FNC, Athena Enzyme Systems, Baltimore, MD).

\section{Gene expression profiling}

Total RNA was isolated from postconfluent CEC cultures, as described. ${ }^{39}$ Passage 2 or 3 cells were grown and cultured 
for 24-38 days, with the addition of hydrocortisone $(0.4 \mu \mathrm{g} /$ $\mathrm{mL}$ ) during the last 7 days of culture. Total RNA was isolated using the RNeasy Mini Kit (QIAGEN, Toronto, ON, CA) and RNA quality was analyzed using the 2100 Bioanalyzer (Agilent Technologies, Mississauga, ON, Canada). All samples had an RNA integrity number over 9.5. Cyanine 3-CTP labeled cRNA targets were prepared from $50 \mathrm{ng}$ of total RNA, using the Agilent One-Color Micro-array-Based Gene Expression Analysis Kit (Agilent Technologies). The cRNA (600 ng) was incubated on a G4851A SurePrint G3 Human Gene Expression $8 \times 60 \mathrm{~K}$ array slide (60,000 probes, Agilent Technologies) and the slides were hybridized and scanned on an Agilent SureScan Scanner according to the manufacturer's instructions. The data were then analyzed using the ArrayStar V12 (DNASTAR, Madison, WI) software for scatter plots and for the generation of heat maps for selected genes of interest. The raw data generated from the arrays were also analyzed by RMA (Robust Multiarray Analysis) for background correction. It was subsequently transformed in $\log _{2}$ base and quantile normalized before a linear model was fitted to the normalized data, to obtain an expression measure for each probe set on each array. The microarray data presented in this study complied with the minimum information about a microarray experiment requirements. ${ }^{40}$

\section{Tissue-engineered human corneal endothelium}

Eye bank corneas were devitalized using three freeze-thaw cycles, ${ }^{36}$ then stored at $-20^{\circ} \mathrm{C}$ until used (range 17-620 days, mean $\pm \mathrm{SD}=88 \pm 106$ days). On the day of reconstruction, they were thawed, rinsed to remove the dead cells, and observed under a stereomicroscope (Nikon SMZ800, Mississauga, ON, Canada). Corneas with detached DM were discarded. Tissue engineering of the corneal endothelium followed our previously published protocol. ${ }^{36}$ In brief, devitalized human corneas were placed in the bottom of a sixwell plate, with the denuded DM facing up. Endothelial cells isolated from healthy $(n=3)$ and $\operatorname{FECD}(n=7)$ corneas were seeded on top of the denuded DM and allowed to adhere for $4 \mathrm{~h}$ before immersion in culture medium. They were further cultured for 1-3 weeks (healthy CECs: from 9 to 16 days, mean $\pm \mathrm{SD}=11 \pm 2$ days; FECD CECs: from 8 to 20 days, mean $\pm S D=13 \pm 3$ days). A flow diagram of the tissue engineering protocol is presented in Figure 1.

\section{Histology}

Tissues were fixed in $3.7 \%$ formaldehyde (ACP Chemicals, Montréal, QC, Canada) and processed for paraffin embedding. Sections $(5 \mu \mathrm{m})$ were stained with Masson's trichrome. Digital images were acquired using an Axio Imager Z2 microscope (Carl Zeiss Canada Ltd., Toronto, ON, Canada).

\section{Indirect immunofluorescence analysis}

Tissues were embedded in Optimal Cutting Temperature compound (Somagen, Edmonton, AB, Canada), frozen in liquid nitrogen and stored at $-80^{\circ} \mathrm{C}$ for ulterior immunostaining. Indirect immunofluorescence assays were performed on $12 \mu \mathrm{m}$ cryosections as follows: for the clusterin/TGF $\beta$ Ip costaining, cryosections were fixed $10 \mathrm{~min}$ at $-20^{\circ} \mathrm{C}$ in methanol (100\%; Commercial Alcohols, Brampton, ON,

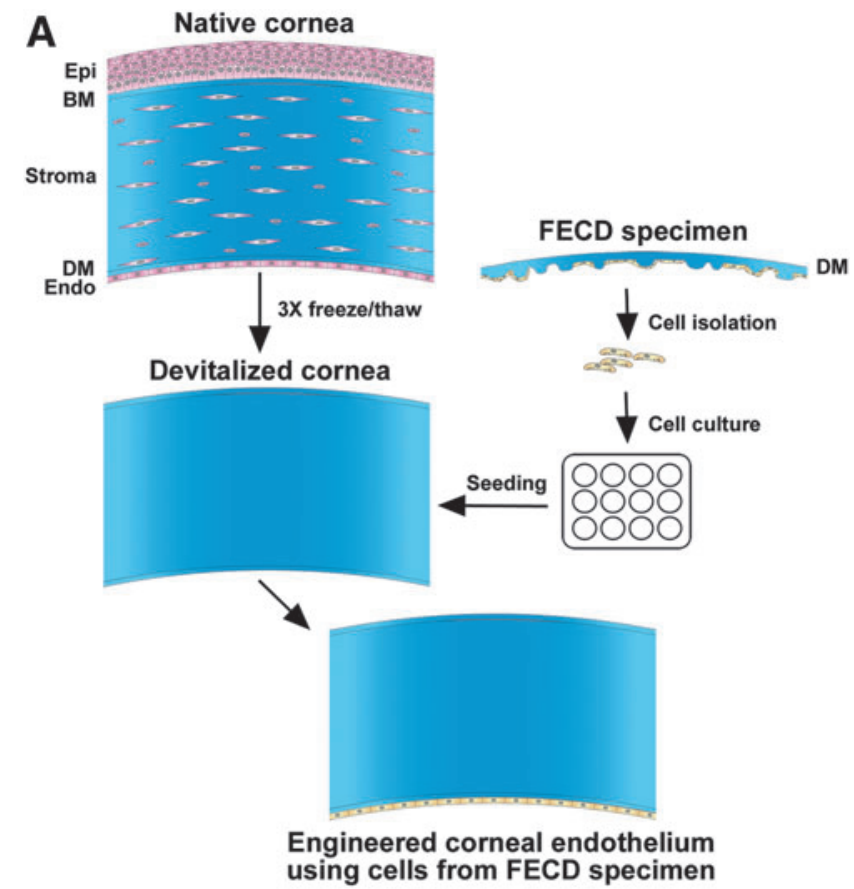

B

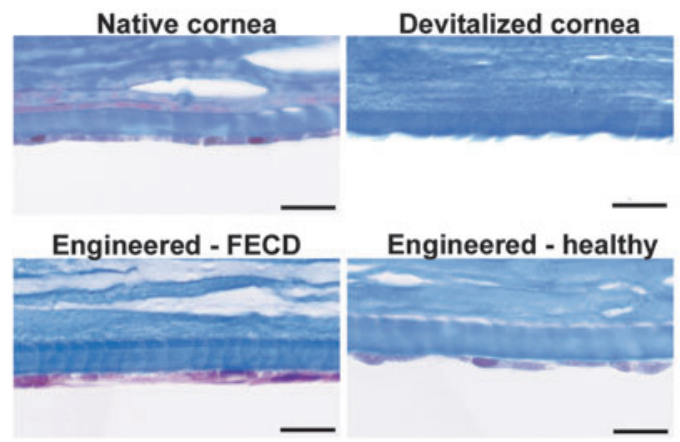

FIG. 1. Schematic representation of the tissue engineering protocol. (A) A healthy eye bank cornea was devitalized following three freeze-thaw cycles and used as a carrier for the engineering of a corneal endothelium using cultured cells isolated from FECD specimens. The same protocol was also used to engineer a corneal endothelium using healthy cells from normal eye bank corneas (not shown). (B) Histology cross-sections, trichrome Masson's staining. Top left: a native human eye bank cornea before devitalization; Top right: a devitalized human cornea before cell seeding. Note the absence of cells in the stroma and on Descemet's membrane; Bottom left: a corneal endothelium engineered using cells from patients with FECD; Bottom right: a corneal endothelium tissue engineered using healthy cells from an eye bank cornea. Scale bar: $20 \mu \mathrm{m}$. FECD, Fuchs endothelial corneal dystrophy.

Canada), permeabilized with Triton-phosphate-buffered saline $1 \%(\mathrm{v} / \mathrm{v})$ for $10 \mathrm{~min}$ and immunostained $2 \mathrm{~h}$ with a mouse anti-clusterin- $\alpha / \beta$ (H-330; Santa Cruz Biotechnology, Dallas, TX), and a goat anti-TGF $\beta$ Ip antibody (E-19; Santa Cruz Biotechnology). For all other immunostainings, cryosections were fixed $10 \mathrm{~min}$ at $-20^{\circ} \mathrm{C}$ with acetone $(90 \%$; EMD, Mississauga, ON, Canada) and immunostained with a rabbit anti-collagen IV (Abcam, Toronto, ON, Canada), a mouse anti-fibronectin (ATCC, Rockville, MD), a rat anti-laminin 
Table 1. Transcriptome Analysis of Extracellular MatriX-Related Genes in Fuchs Endothelial Corneal Dystrophy Cultured Cells

\begin{tabular}{|c|c|c|c|}
\hline Gene name & $\begin{array}{c}\text { Mean linear } \\
\text { value } \pm S D\end{array}$ & $\begin{array}{l}\text { Fold change } \\
\text { relative to } \\
\text { healthy controls }\end{array}$ & $\mathrm{p}$ \\
\hline \multicolumn{4}{|l|}{ Collagen genes } \\
\hline COL1A1 & $823 \pm 676$ & 1.0 & 0.966 \\
\hline COL1A2 & $13955 \pm 5286$ & -1.2 & 0.476 \\
\hline COL3A1 & $260 \pm 130$ & -1.4 & 0.418 \\
\hline COLAAI & $246 \pm 374$ & -1.3 & 0.829 \\
\hline COLAA2 & $2990 \pm 3582$ & -1.2 & 0.808 \\
\hline COLAA3BP & $705 \pm 128$ & 1.1 & 0.236 \\
\hline COLAA4 & $298 \pm 225$ & -2.3 & 0.329 \\
\hline COLAA5 & $1630 \pm 437$ & -1.1 & 0.591 \\
\hline COLAA6 & $2043 \pm 742$ & -1.2 & 0.311 \\
\hline COL5A1 & $361 \pm 170$ & -1.3 & 0.471 \\
\hline COL5A2 & $5303 \pm 1639$ & -1.2 & 0.451 \\
\hline COL6A1 & $7333 \pm 4739$ & 1.1 & 0.697 \\
\hline COL6A2 & $344 \pm 524$ & 2.2 & 0.426 \\
\hline COL7A1 & $526 \pm 210$ & -1.4 & 0.132 \\
\hline COL8A1 & $11144 \pm 4428$ & -1.7 & 0.052 \\
\hline COL8A2 & $823 \pm 967$ & -2.6 & 0.146 \\
\hline COL9A3 & $2178 \pm 3370$ & 1.7 & 0.528 \\
\hline COL12A1 & $11575 \pm 6420$ & -1.5 & 0.274 \\
\hline COL13A1 & $692 \pm 362$ & 1.4 & 0.376 \\
\hline COL16A1 & $1580 \pm 801$ & 1.3 & 0.453 \\
\hline COL18A1 & $2698 \pm 1685$ & 1.2 & 0.648 \\
\hline COL21A1 & $98 \pm 61$ & -2.0 & 0.206 \\
\hline COL24A1 & $119 \pm 44$ & -1.5 & 0.306 \\
\hline \multicolumn{4}{|c|}{ Fibronectin genes } \\
\hline FN1 & $1402 \pm 1998$ & 1.5 & 0.648 \\
\hline$F N D C 3 A$ & $140 \pm 65$ & -1.2 & 0.532 \\
\hline$F N D C 3 B$ & $439 \pm 131$ & 1.1 & 0.751 \\
\hline FNDC4 & $350 \pm 86$ & 1.8 & $0.022^{\mathrm{a}}$ \\
\hline \multicolumn{4}{|l|}{ Laminin genes } \\
\hline LAMA3 & $559 \pm 796$ & 2.8 & 0.313 \\
\hline LAMA4 & $318 \pm 79$ & 1,1 & 0.588 \\
\hline LAMA5 & $314 \pm 70$ & 1.1 & 0.454 \\
\hline$L A M B 1$ & $360 \pm 35$ & 1.0 & 0.771 \\
\hline$L A M B 2$ & $5957 \pm 1634$ & -1.2 & 0.370 \\
\hline$L A M B 3$ & $249 \pm 176$ & 1.9 & 0.163 \\
\hline$L A M C 1$ & $1589 \pm 731$ & -1.1 & 0.660 \\
\hline$L A M C 2$ & $238 \pm 145$ & -1.2 & 0.713 \\
\hline \multicolumn{4}{|l|}{ Other } \\
\hline$C L U$ & $6668 \pm 5069$ & -1.3 & 0.508 \\
\hline CLUAP1 & $342 \pm 80$ & -1.1 & 0.740 \\
\hline$T G F B I$ & $38176 \pm 5415$ & 1.3 & 0.105 \\
\hline
\end{tabular}

Genes with linear values under 100 were excluded. Bold indicates a twofold down- or upregulation.

${ }^{\mathrm{a}}$ Means significantly different $(p<0.05)$.

FNDC4, fibronectin type III domain containing 4; SD, standard deviation.

(Abcam), a mouse anti-integrin $\alpha 4$ (Millipore, Temecula, CA), a mouse anti-integrin $\alpha 5$ (Transduction laboratories, Mississauga, ON, Canada), a mouse anti-integrin $\alpha 6$ (Serotec, Burlington, ON, Canada), a rabbit anti-integrin $\alpha \mathrm{v}$ (Millipore), or a mouse anti-integrin $\beta 1$ (ATCC) for $1 \mathrm{~h}$ at room temperature. Secondary antibodies consisted of a goat anti-rabbit, a goat anti-rat, a chicken anti-rabbit, a donkey anti-mouse conjugated with Alexa Fluor 594 (Life technologies, Burlington, ON, Canada) and a donkey anti-goat antibody con- jugated with Alexa Fluor 647 (Abcam) for $1 \mathrm{~h}$ at room temperature. Negligible background was observed for controls (primary antibodies omitted). Cell nuclei were counterstained with Hoechst reagent 33258 (Sigma). Fluorescence was observed using a LSM700 confocal microscope (Zeiss, Toronto, ON, Canada).

\section{Statistical analysis}

Quantified data represent the mean \pm SD wherever applicable. Statistical significance was determined using the nonparametric Mann-Whitney U-test (GraphPad Prism version 5), which does not assume Gaussian distribution. A $p<0.05$ was considered significant.

\section{Results}

\section{ECM- and integrin-related gene expression}

Gene expression profiling by microarray analysis was conducted on total RNAs isolated from cultured CECs from healthy and FECD specimens. Tables 1 and 2 summarize the ECM and integrin-related genes that had a mean linear value over 100. A high degree of variability was observed between samples (high SD values). Results show that $13 \%$ (5 out of 38 ) ECM-related genes and 6\% (1 out of 18) integrin-related genes had a twofold change deregulation in FECD cells compared with healthy controls. The most abundant mRNAs (linear value over 10,000), in both FECD and healthy cultured CECs, were the ones expressed by COL1A2, COL8A1, COL12A1, and TGFBI. Mean linear values of genes with a twofold (or over) deregulation are represented in Figure 2. In FECD cells, downregulated genes included COLAA4, COL8A2, COL21A1, and ITGA10, while COL6A2 and LAMA3 were

TABLE 2. TRANSCRIPTOME ANALYSIS OF

INTEGRIN-RELATED GENES IN FuCHS ENDOTHELIAL Corneal Dystrophy-Cultured Cells

\begin{tabular}{lccc}
\hline Gene name & $\begin{array}{c}\text { Mean linear } \\
\text { value } \pm S D\end{array}$ & $\begin{array}{c}\text { Fold change } \\
\text { relative to } \\
\text { healthy controls }\end{array}$ & $\mathrm{p}$ \\
\hline Integrin genes & $121 \pm 51$ & -1.4 & 0.161 \\
ITGA1 & $1409 \pm 439$ & 1.0 & 0.843 \\
ITGA3 & $336 \pm 224$ & 1.6 & 0.262 \\
ITGA4 & $744 \pm 488$ & 1.8 & 0.147 \\
ITGA5 & $684 \pm 317$ & 1.7 & 0.102 \\
ITGA6 & $1341 \pm 1476$ & 1.1 & 0.881 \\
ITGA7 & $494 \pm 372$ & -2.4 & 0.273 \\
ITGA10 & $494 \pm 476$ & 1.2 & 0.771 \\
ITGA11 & $428 \pm 303$ & 1.4 & 0.375 \\
ITGAE & $3978 \pm 833$ & 1.0 & 0.907 \\
ITGAV & $162 \pm 117$ & 1.1 & 0.863 \\
ITGB1 & $224 \pm 84$ & 1.1 & 0.721 \\
INTGB1BP1 & $196 \pm 104$ & 1.0 & 0.939 \\
ITGB3 & $411 \pm 361$ & 1.6 & 0.399 \\
ITGB3BP & $933 \pm 676$ & -1.6 & 0.239 \\
ITGB4 & $6051 \pm 1667$ & 1.4 & $0.049^{\mathrm{a}}$ \\
ITGB5 & $100 \pm 47$ & 1.2 & 0.441 \\
ITGB7 & $3292 \pm 1311$ & -1.3 & 0.228 \\
ITGBL1 & &
\end{tabular}

Genes with linear values under 100 were excluded. Bold indicates a twofold down- or upregulation.

${ }^{\mathrm{a}}$ Means significantly different $(p<0.05)$. 


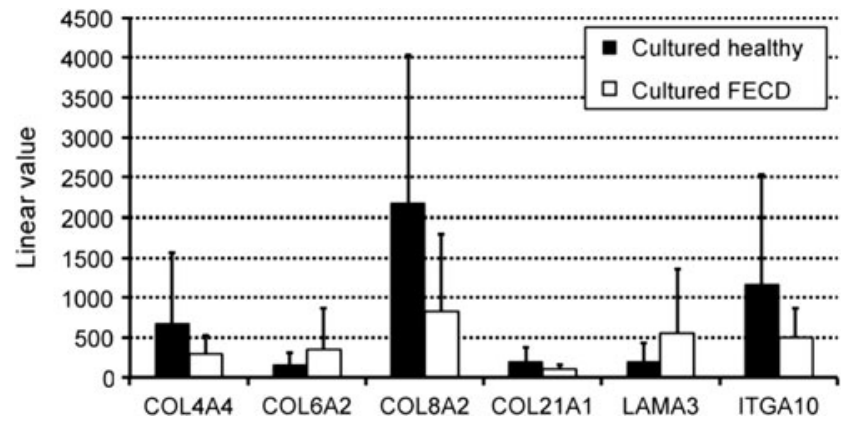

FIG. 2. Microarray analysis. Linear values of the microarray analysis of genes of interests. Healthy specimens (black bars) and FECD specimens (white bars).

upregulated, however, none of these deregulated genes showed statistical significance. The only deregulated genes with a $p$ value under 0.05 were the ones coding for the fibronectin type III domain containing 4 (FNDC4) and the integrin $\beta 5$ subunit (ITGB5) (Tables 1 and 2).

\section{ECM- and integrin-related protein expression}

We then examined the protein expression of these ECM and integrin-related genes, especially type IV collagen, laminin, and fibronectin, since they were previously reported to be deregulated in native FECD tissues. ${ }^{2,13}$ To do so, healthy or FECD cells were seeded on a previously decellularized DM (Fig. 1A) to engineer a corneal endothelium. As shown in the histology cross sections (Fig. 1B), the engineered endothelium formed a monolayer of tightly-packed cells, similar to the native endothelium. Native tissues were used as controls for the immunostaining. A summary of the immunostaining results of ECM- and integrin-related proteins is presented in Table 3.

Table 3. Summary of Extracellular-Matrix-Related Proteins and Integrin Subunits Detected BY IMMUNOFLUORESCENCE

\begin{tabular}{|c|c|c|c|c|}
\hline & $\begin{array}{l}\text { Native } \\
\text { healthy }\end{array}$ & $\begin{array}{l}\text { Native } \\
\text { FECD }\end{array}$ & $\begin{array}{c}\text { Engineered } \\
\text { healthy }\end{array}$ & $\begin{array}{c}\text { Engineered } \\
F E C D\end{array}$ \\
\hline \multicolumn{5}{|c|}{ Extracellular matrix proteins } \\
\hline Col IV & + & + to ++ & + to ++ & + to ++ \\
\hline LM & + & $(+)$ & + & + \\
\hline $\mathrm{FN}$ & $(+)$ & ++ & $(+)$ & + to ++ \\
\hline CLU & - & + & - & - \\
\hline TGF $\beta$ Ip & $+^{\mathrm{a}}$ & $+^{\mathrm{a}}$ & $+^{\mathrm{a}}$ & $+^{\mathrm{a}}$ \\
\hline \multicolumn{5}{|c|}{ Integrin proteins } \\
\hline Int $\alpha 4$ & + & + & + & + \\
\hline Int $\alpha 6$ & $(+)$ to + & $(+)$ & $(+)$ & $(+)$ \\
\hline Int $\alpha v$ & $(+)$ to + & $(+)$ & + & + \\
\hline Int $\beta 1$ & $(+)$ & $(+)$ & + & + \\
\hline
\end{tabular}

Intensity grading: ++ strong positive staining; + positive staining; $(+)$ weak positive staining; - absence of staining.

a note that the staining was only present on the stromal side of Descemet's membrane (thus was not recently deposited by endothelial cells).

Col IV, type IV collagen; LM, laminin; FECD, Fuchs endothelial corneal dystrophy; FN, fibronectin; CLU, clusterin; TGF $\beta I$, transforming growth factor $\beta$-induced protein; Int, integrin.
The native DM normally expresses type IV collagen as a thin line on its endothelial side (Fig. 3). A similar expression was observed in native FECD specimens, as well as in healthy and FECD-engineered endothelia (Fig. 3). Laminin protein expression was also observed in all specimens, without obvious differences between native healthy and engineered (healthy or FECD) tissues, and a weaker expression in native FECD specimens (Fig. 3). Fibronectin protein expression, on the contrary, was markedly increased in both native and engineered FECD specimens (Fig. 3).

The $\alpha 4$ integrin subunit was similarly expressed in all tissues (Fig. 4), while the $\alpha 5$ subunit was not detected in any of our samples (not shown). Integrin subunits $\alpha 6$ and $\alpha \mathrm{v}$ were present on all samples with a fainter expression in native FECD specimens. The protein expression of the integrin $\beta 1$ subunit was stronger in both engineered tissues (Fig. 4).

An immunostaining of the glycoprotein clusterin, known to cause cell aggregation and induce the formation of junctional contacts between cells, ${ }^{41}$ was performed in combination with TGF $\beta$ Ip, an ECM protein that mediates cell adhesion by interacting with collagens, fibronectin, and integrins proteins, mainly $\alpha 3 \beta 1^{42,43}$ (Fig. 5). In healthy and FECD native and engineered corneas, TGF $\beta$ Ip was generally expressed on the stromal side of DMs, with punctate staining also observed within DMs. Only a very faint cellular TGF $\beta$ Ip expression was observed within CECs. Clusterin was only observed in one guttae of a native FECD specimen and never in FECD-engineered corneas.

\section{Discussion}

This study shows that cultured FECD cells carry the disease phenotype in vitro. The endothelia engineered using FECD cells showed a greater deposition of fibronectin than their healthy counterpart, as early as 1-3 weeks after seeding. Fibronectin accumulation was observed without deregulation of laminin and type IV collagen, which were similarly expressed and distributed in the engineered tissues. Since laminin and type IV collagen were previously shown to be increased in late-stage FECD ${ }^{12-14}$ our results suggest that fibronectin deposition precedes deregulation of these proteins, which is compatible with the chronicity of the disease. Several decades usually separate the appearance of the first guttae and late-stage endothelial decompensation necessitating endothelial transplantation. In our model, fibronectin deposition was the earliest detected sign of FECD pathogenesis.

Our results also demonstrate a high degree of variability in gene expression among FECD specimens. This is in accordance with previous observations showing significant variation in DM phenotype in terms of membrane thickness, presence and amount of striated bodies, guttae shape, size and distribution, and presence or absence of a fibrillar layer. $6,9-11,44$ TGF $\beta$ Ip and clusterin have previously been shown to colocalize at the guttae of FECD DM. ${ }^{15,16}$ In the present study, TGF $\beta$ Ip and clusterin expression was both present in one out of three native FECD specimens, however, the two proteins did not colocalize. These results converge to suggest the existence of different subtypes of late-onset FECD, despite a similar clinical endpoint. While the sample size of this study did not lead to the identification of disease-associated genes, larger studies may, in time, 


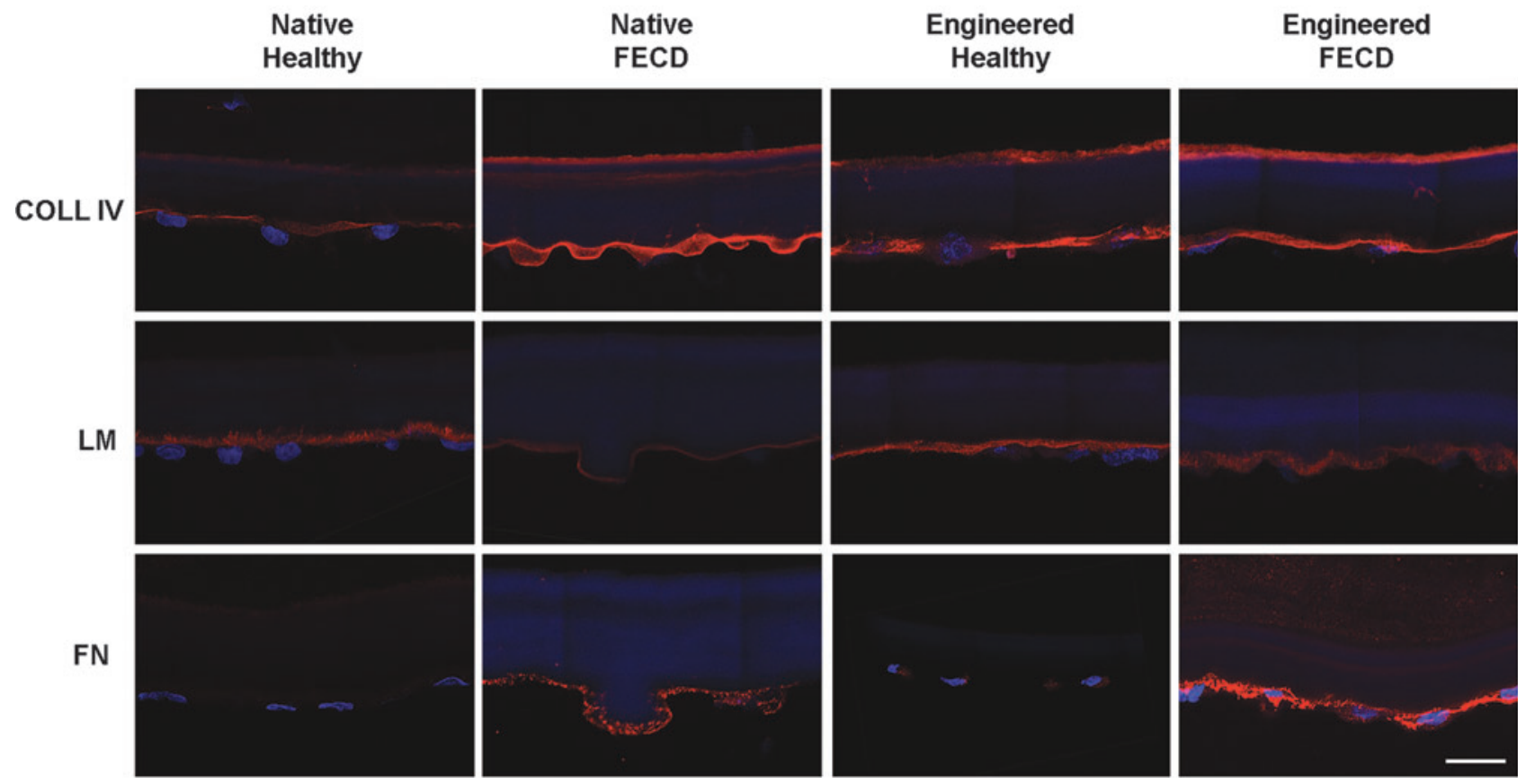

FIG. 3. Extracellular matrix-related protein expression. Immunofluorescent staining (red) of type IV collagen (COL IV), laminin (LM) and fibronectin (FN) on healthy and FECD native tissues, as well as on corneal endothelia engineered using healthy and FECD cells. Cell nuclei were counterstained with Hoechst (blue). Descemet membranes are oriented stromal side up and endothelial side down. Scale bar: $20 \mu \mathrm{m}$.

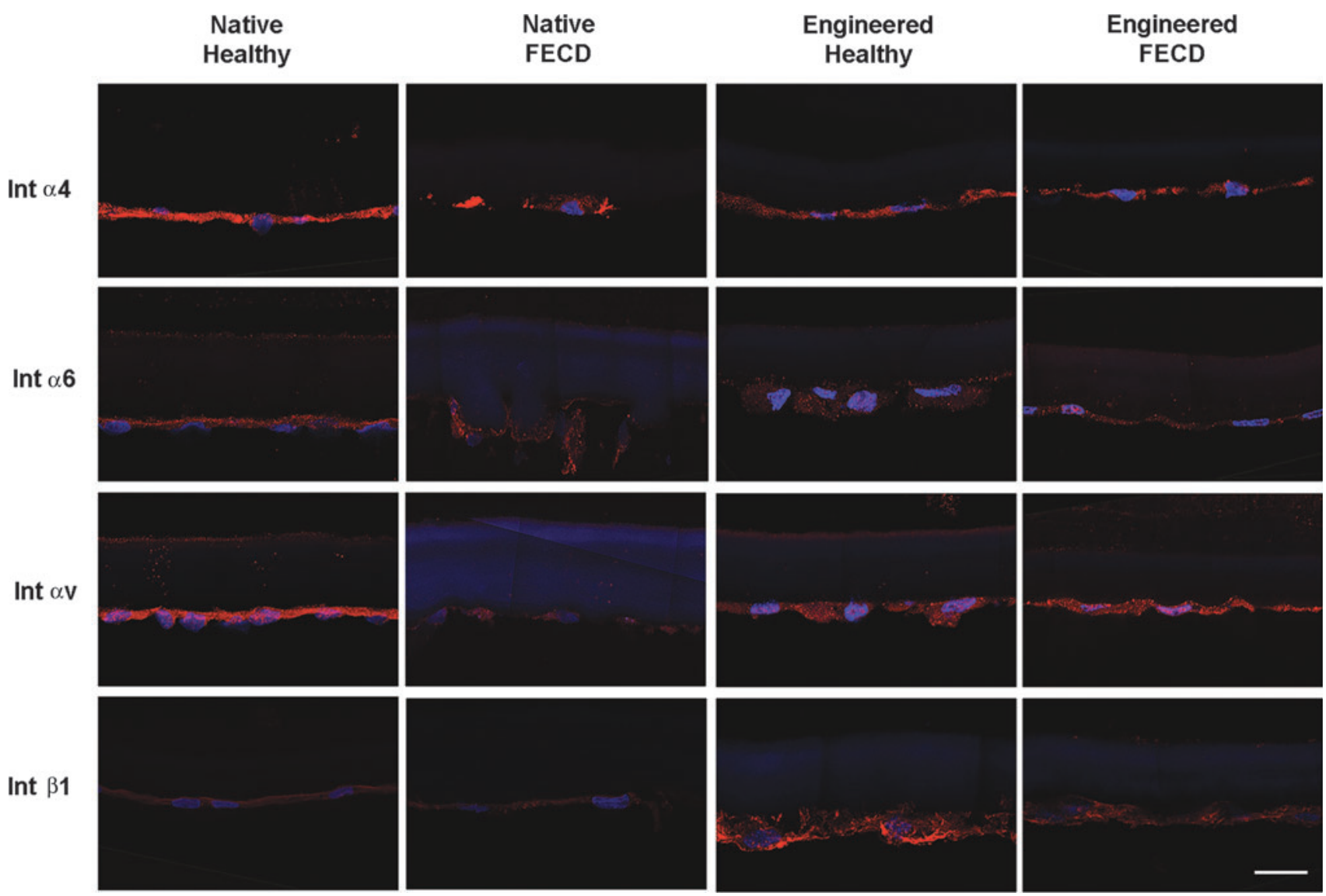

FIG. 4. Integrins protein expression. Immunofluorescent staining (red) of integrin subunits $\alpha 4, \alpha 6, \alpha \mathrm{v}$, and $\beta 1$ on healthy and FECD native tissues, as well as on corneal endothelia engineered using healthy and FECD cells. Cell nuclei were counterstained with Hoechst (blue). Descemet membranes are oriented stromal side up and endothelial side down. Scale bar: $20 \mu \mathrm{m}$. 


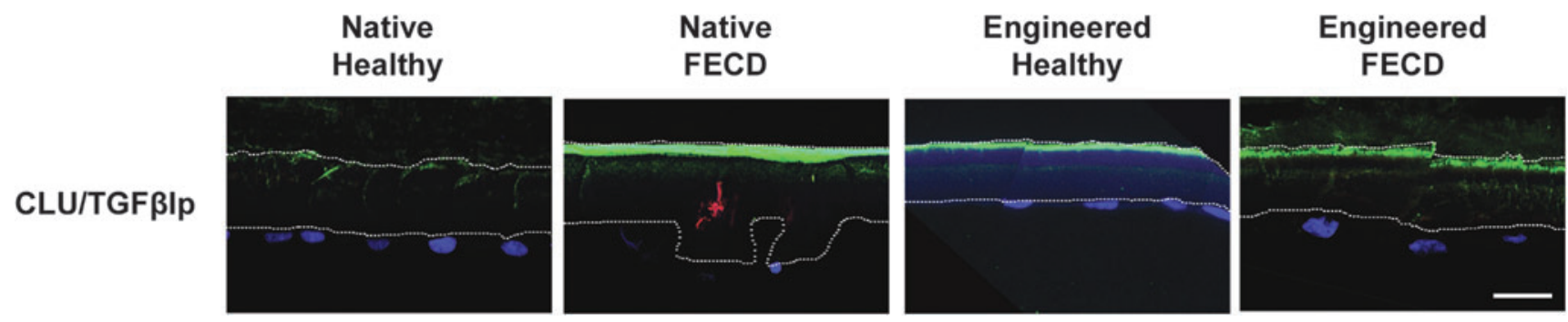

FIG. 5. Clusterin and TGF $\beta$ Ip protein expression. Immunofluorescent staining of clusterin by (CLU; red) and TGF $\beta$ Ip (green) on healthy and FECD native tissues, as well as on corneal endothelia engineered using healthy and FECD cells. Cell nuclei were counterstained with Hoechst (blue). Descemet membranes are oriented stromal side up and endothelial side down. A white line delineates Descemet membranes. Scale bar: $20 \mu \mathrm{m}$.

allow the separation of different FECD subtypes according to sets of deregulated genes.

The mutation $\mathrm{L} 450 \mathrm{~W}$ in the COL8A2 gene causes an improper accumulation (between 2.3 and 5.8-fold) of the collagen type VIII $\alpha 2$ protein in DMs, ${ }^{45}$ resulting in guttae formation and reduced endothelial cell counts. ${ }^{46}$ COL8A2 mutations (L450W and Q455V) have been identified in a rare familial early-onset subtype of FECD..$^{12,13,47-52}$ We did not observe an overexpression of COL8A2 in FECD-cultured cells. One explanation is that the specimens used herein were all obtained from patients with late-onset FECD. Indeed, screening of patients with this subtype of the disease has repeatedly failed to document $C O L 8 A 2$ mutations $^{53-55}$ or COL8A2 gene and protein expression deregulation. ${ }^{14,56}$

The increased deposition of fibronectin by the FECD cells is in accordance with our previous experiments showing an early and enhanced deposition of ECM in a short-term living model of FECD. ${ }^{37}$ Given this increased accumulation of fibronectin in FECD, it is surprising not to find any significant deregulation of the integrins binding this ECM protein (integrins $\alpha 4 \beta 1, \alpha 4 \beta 7, \alpha 5 \beta 1$, and $\alpha \mathrm{v} \beta 3$ ) at both the gene and the protein levels. Indeed, the integrin genes ITGA4, ITGA5, $I T G A V$, ITGB1, and ITGB7, as well as the integrin proteins $\alpha 4, \alpha v$, and $\beta 1$ were all similarly expressed in the cultured cells and in the endothelia engineered using healthy and FECD cells. Of interest, the integrin $\beta 5$ subunit gene ITGB5 was significantly ( $p=0.049)$ slightly upregulated (1.4-fold) in FECD cells. The $\beta 5$ integrin subunit is only known to bind with $\alpha v$, and integrin $\alpha v \beta 5$ also has fibronectin as one of its ligands. ${ }^{57}$ Considering ITGB5 was the integrin subunit with the highest linear signal, it could be meaningful to address its role in FECD pathogenesis.

The $\beta 1$ integrin subunit showed a higher protein expression in the engineered endothelia compared with the native tissues (for both healthy and FECD). This suggests that cell culture, rather than the disease, is responsible for the upregulation of this integrin subunit. An upregulation of the $\beta 1$ subunit could benefit the engineering of a corneal endothelium by enhancing the adhesion to a carrier or to the native DM. The endothelial side of the DM is indeed rich in laminin, ${ }^{3,4}$ a protein that interacts with integrins $\alpha 3 \beta 1$, $\alpha 6 \beta 1$, and $\alpha 7 \beta 1$. $^{17}$

Interestingly and contrary to native tissue, ${ }^{14}$ very few genes and proteins were deregulated in cultured FECD cells compared with cultured healthy cells. This observation supports the hypothesis that cell culture may select the less affected cells, allowing to engineer a functional endothelium using cells harvested from late stage FECD, as reported previously by our group. ${ }^{37}$

To conclude, our results point to an early implication of fibronectin in the pathogenesis of the disease. This increase in fibronectin seems to precede the accumulation of laminin and type IV collagen at the posterior side of DM, as well as the increase in clusterin and TGF $\beta$ Ip colocalized at the guttae that have been described in the late stages of the disease. Fibronectin plays an important role in the regulation of cell migration, adhesion, growth, differentiation, and apoptosis. ${ }^{25}$ Our engineered tissue model could thus be used to further study the consequence and implication of the accumulation of fibronectin and other proteins in FECD, with the hope that early pharmacological inhibition would slow down progression of the disease and eventually avoid corneal transplantation.

\section{Acknowledgments}

This work was supported by the "Fondation des hôpitaux HSS et HEJ" (S.P.), the Canadian Institutes of Health Research (I.B., S.P., P.J.R.) and the "Fonds de recherche du Québec-Santé" (FRQ-S) TheCell Network. Procurement of eyes and corneas for research from the CUO Eye bank was possible thanks to the FRQ-S Vision Health Research Network Infrastructure Program. I.B. is the recipient of the Charles-Albert Poissant Research Chair in Corneal Transplantation, University of Montreal, Canada. P.J.R is a research scholar from the FRQ-S and S.P. is a research scholar from the FRQ-S in partnership with the "Fondation Antoine Turmel." The authors thank Drs. Richard Bazin, Patricia-Ann Laughrea, and Marie-Ėve Légaré from the CUO; Drs. Mona Harrissi-Dagher, Louis Racine, Paul Thompson, and MarieClaude Robert from the CHUM and Dre Johanna Choremis from HMR for their ongoing collaboration in obtaining the FECD specimens; Myriam Bareille, Danièle Caron, Patrick Carrier, Karolyn Forget, Marie-Claude Perron, Jeanne d'Arc Uwamaliya, and the CUO de Québec and HMR-Rosemont operating room nurses for their technical assistance; Karine Zaniolo and Sylvain Guérin for the microarrays; Olivier Rochette Drouin for technical assistance and the LOEX research assistants for the histology preparations.

\section{Disclosure Statement}

No competing financial interests exist. 


\section{References}

1. Waring, G.O., 3rd, Bourne, W.M., Edelhauser, H.F., and Kenyon, K.R. The corneal endothelium. Normal and pathologic structure and function. Ophthalmology 89, 531, 1982.

2. EBAA. 2015 Eye Banking Statistical Report. Washington D.C, 2016. http://restoresight.org/wp-content/uploads/2016/ 03/2015-Statistical-Report.pdf (accessed September 15, 2017).

3. Levy, S.G., Moss, J., Sawada, H., Dopping-Hepenstal, P.J., and McCartney, A.C. The composition of wide-spaced collagen in normal and diseased Descemet's membrane. Curr Eye Res 15, 45, 1996.

4. Ljubimov, A.V., Burgeson, R.E., Butkowski, R.J., Michael, A.F., Sun, T.T., and Kenney, M.C. Human corneal basement membrane heterogeneity: topographical differences in the expression of type IV collagen and laminin isoforms. Lab Invest 72, 461, 1995.

5. Johnson, D.H., Bourne, W.M., and Campbell, R.J. The ultrastructure of Descemet's membrane. I. Changes with age in normal corneas. Arch Ophthalmol 100, 1942, 1982.

6. Yuen, H.K., Rassier, C.E., Jardeleza, M.S., Green, W.R., de la Cruz, Z., Stark, W.J., et al. A morphologic study of Fuchs dystrophy and bullous keratopathy. Cornea 24, 319, 2005.

7. Naumann, G.O., and Schlotzer-Schrehardt, U. Keratopathy in pseudoexfoliation syndrome as a cause of corneal endothelial decompensation: a clinicopathologic study. Ophthalmology 107, 1111, 2000.

8. Shousha, M.A., Perez, V.L., Wang, J., Ide, T., Jiao, S., Chen, Q., et al. Use of ultra-high-resolution optical coherence tomography to detect in vivo characteristics of Descemet's membrane in Fuchs' dystrophy. Ophthalmology 117, 1220, 2010.

9. Iwamoto, T., and DeVoe, A.G. Electron microscopic studies on Fuchs'combined dystrophy. I. Posterior portion of the cornea. Invest Ophthalmol 10, 9, 1971.

10. Bourne, W.M., Johnson, D.H., and Campbell, R.J. The ultrastructure of Descemet's membrane. III. Fuchs' dystrophy. Arch Ophthalmol 100, 1952, 1982.

11. Zaniolo, K., Bostan, C., Rochette Drouin, O., Deschambeault, A., Perron, M.C., Brunette, I., et al. Culture of human corneal endothelial cells isolated from corneas with Fuchs endothelial corneal dystrophy. Exp Eye Res 94, 22, 2012.

12. Gottsch, J.D., Zhang, C., Sundin, O.H., Bell, W.R., Stark, W.J., and Green, W.R. Fuchs corneal dystrophy: aberrant collagen distribution in an L450 W mutant of the COL8A2 gene. Invest Ophthalmol Vis Sci 46, 4504, 2005.

13. Zhang, C., Bell, W.R., Sundin, O.H., De La Cruz, Z., Stark, W.J., Green, W.R., et al. Immunohistochemistry and electron microscopy of early-onset fuchs corneal dystrophy in three cases with the same L450W COL8A2 mutation. Trans Am Ophthalmol Soc 104, 85, 2006.

14. Weller, J.M., Zenkel, M., Schlotzer-Schrehardt, U., Bachmann, B.O., Tourtas, T., and Kruse, F.E. Extracellular matrix alterations in late-onset Fuchs' corneal dystrophy. Invest Ophthalmol Vis Sci 55, 3700, 2014.

15. Jurkunas, U.V., Bitar, M., and Rawe, I. Colocalization of increased transforming growth factor-beta-induced protein (TGFBIp) and Clusterin in Fuchs endothelial corneal dystrophy. Invest Ophthalmol Vis Sci 50, 1129, 2009.

16. Jurkunas, U.V., Bitar, M.S., Rawe, I., Harris, D.L., Colby, K., and Joyce, N.C. Increased clusterin expression in Fuchs' endothelial dystrophy. Invest Ophthalmol Vis Sci 49, 2946, 2008.

17. Hynes, R.O. Integrins: bidirectional, allosteric signaling machines. Cell 110, 673, 2002.
18. Vigneault, F., Zaniolo, K., Gaudreault, M., Gingras, M.E., and Guerin, S.L. Control of integrin genes expression in the eye. Prog Retin Eye Res 26, 99, 2007.

19. Takada, Y., Ye, X., and Simon, S. The integrins. Genome Biol 8, 215, 2007.

20. Elner, S.G., and Elner, V.M. The integrin superfamily and the eye. Invest Ophthalmol Vis Sci 37, 696, 1996.

21. Legate, K.R., and Fassler, R. Mechanisms that regulate adaptor binding to beta-integrin cytoplasmic tails. J Cell Sci 122, 187, 2009.

22. Wiesner, S., Legate, K.R., and Fassler, R. Integrin-actin interactions. Cell Mol Life Sci 62, 1081, 2005.

23. Shattil, S.J., Kim, C., and Ginsberg, M.H. The final steps of integrin activation: the end game. Nat Rev Mol Cell Biol 11, 288, 2010.

24. Cordes, N., and Park, C.C. beta1 integrin as a molecular therapeutic target. Int J Radiat Biol 83, 753, 2007.

25. Aota, S., and Yamada, K.M. Fibronectin and cell adhesion: specificity of integrin-ligand interaction. Adv Enzymol Relat Areas Mol Biol 70, 1, 1995.

26. Wehrle-Haller, B., and Imhof, B.A. Integrin-dependent pathologies. J Pathol 200, 481, 2003.

27. Lowell, C.A., and Mayadas, T.N. Overview: studying integrins in vivo. Methods Mol Biol 757, 369, 2012.

28. Choi, J.S., Kim, E.Y., Kim, M.J., Giegengack, M., Khan, F.A., Khang, G., et al. In vitro evaluation of the interactions between human corneal endothelial cells and extracellular matrix proteins. Biomed Mater 8, 014108, 2013.

29. Kenney, M.C., Labermeier, U., Hinds, D., and Waring, G.O., 3rd. Characterization of the Descemet's membrane/ posterior collagenous layer isolated from Fuchs' endothelial dystrophy corneas. Exp Eye Res 39, 267, 1984.

30. Borderie, V.M., Baudrimont, M., Vallee, A., Ereau, T.L., Gray, F., and Laroche, L. Corneal endothelial cell apoptosis in patients with Fuchs' dystrophy. Invest Ophthalmol Vis Sci 41, 2501, 2000.

31. Gottsch, J.D., Seitzman, G.D., Margulies, E.H., Bowers, A.L., Michels, A.J., Saha, S., et al. Gene expression in donor corneal endothelium. Arch Ophthalmol 121, 252, 2003.

32. Elhalis, H., Azizi, B., and Jurkunas, U.V. Fuchs endothelial corneal dystrophy. Ocul Surf 8, 173, 2010.

33. Proulx, S., Bourget, J.M., Gagnon, N., Martel, S., Deschambeault, A., Carrier, P., et al. Optimization of culture conditions for porcine corneal endothelial cells. Mol Vis 13, 524, 2007.

34. Proulx, S., d'Arc Uwamaliya, J., Carrier, P., Deschambeault, A., Audet, C., Giasson, C.J., et al. Reconstruction of a human cornea by the self-assembly approach of tissue engineering using the three native cell types. Mol Vis 16, 2192, 2010.

35. Proulx, S., Bensaoula, T., Nada, O., Audet, C., d'Arc Uwamaliya, J., Devaux, A., et al. Transplantation of a tissueengineered corneal endothelium reconstructed on a devitalized carrier in the feline model. Invest Ophthalmol Vis Sci 50, 2686, 2009.

36. Proulx, S., Audet, C., Uwamaliya, J., Deschambeault, A., Carrier, P., Giasson, C.J., et al. Tissue engineering of feline corneal endothelium using a devitalized human cornea as carrier. Tissue Eng Part A 15, 1709, 2009.

37. Haydari, M.N., Perron, M.C., Laprise, S., Roy, O., Cameron, J.D., Proulx, S., et al. A short-term in vivo experimental model for Fuchs endothelial corneal dystrophy. Invest Ophthalmol Vis Sci 53, 6343, 2012.

38. Joyce, N.C., and Zhu, C.C. Human corneal endothelial cell proliferation: potential for use in regenerative medicine. Cornea 23, S8, 2004. 
39. Gendron, S.P., Theriault, M., Proulx, S., Brunette, I., and Rochette, P.J. Restoration of mitochondrial integrity, telomere length, and sensitivity to oxidation by in vitro culture of Fuchs' endothelial corneal dystrophy cells. Invest Ophthalmol Vis Sci 57, 5926, 2016.

40. Brazma, A., Hingamp, P., Quackenbush, J., Sherlock, G., Spellman, P., Stoeckert, C., et al. Minimum information about a microarray experiment (MIAME)-toward standards for microarray data. Nat Genet 29, 365, 2001.

41. Schwochau, G.B., Nath, K.A., and Rosenberg, M.E. Clusterin protects against oxidative stress in vitro through aggregative and nonaggregative properties. Kidney Int 53, 1647, 1998.

42. Runager, K., Enghild, J.J., and Klintworth, G.K. Focus on molecules: transforming growth factor beta induced protein (TGFBIp). Exp Eye Res 87, 298, 2008.

43. Billings, P.C., Whitbeck, J.C., Adams, C.S., Abrams, W.R., Cohen, A.J., Engelsberg, B.N., et al. The transforming growth factor-beta-inducible matrix protein (beta)ig-h3 interacts with fibronectin. J Biol Chem 277, 28003, 2002.

44. Bergmanson, J.P., Sheldon, T.M., and Goosey, J.D. Fuchs' endothelial dystrophy: a fresh look at an aging disease. Ophthalmic Physiol Opt 19, $210,1999$.

45. Kelliher, C., Chakravarti, S., Vij, N., Mazur, S., Stahl, P.J., Engler, C., et al. A cellular model for the investigation of Fuchs' endothelial corneal dystrophy. Exp Eye Res 93, 880, 2011.

46. Matthaei, M., Hu, J., Meng, H., Lackner, E.M., Eberhart, C.G., Qian, J., et al. Endothelial cell whole genome expression analysis in a mouse model of early-onset Fuchs' endothelial corneal dystrophy. Invest Ophthalmol Vis Sci 54, 1931, 2013.

47. Biswas, S., Munier, F.L., Yardley, J., Hart-Holden, N., Perveen, R., Cousin, P., et al. Missense mutations in COL8A2, the gene encoding the alpha2 chain of type VIII collagen, cause two forms of corneal endothelial dystrophy. Hum Mol Genet 10, 2415, 2001.

48. Kobayashi, A., Fujiki, K., Murakami, A., Kato, T., Chen, L.Z., Onoe, H., et al. Analysis of COL8A2 gene mutation in Japanese patients with Fuchs' endothelial dystrophy and posterior polymorphous dystrophy. Jpn J Ophthalmol 48, 195, 2004.

49. Gottsch, J.D., Sundin, O.H., Liu, S.H., Jun, A.S., Broman, K.W., Stark, W.J., et al. Inheritance of a novel COL8A2 mutation defines a distinct early-onset subtype of fuchs corneal dystrophy. Invest Ophthalmol Vis Sci 46, 1934, 2005.

50. Liskova, P., Prescott, Q., Bhattacharya, S.S., and Tuft, S.J. British family with early-onset Fuchs' endothelial corneal dystrophy associated with p.L450W mutation in the COL8A2 gene. Br J Ophthalmol 91, 1717, 2007.

51. Mok, J.W., Kim, H.S., and Joo, C.K. Q455V mutation in COL8A2 is associated with Fuchs' corneal dystrophy in Korean patients. Eye (Lond) 23, 895, 2009.

52. Minear, M.A., Li, Y.J., Rimmler, J., Balajonda, E., Watson, S., Allingham, R.R., et al. Genetic screen of African Americans with Fuchs endothelial corneal dystrophy. Mol Vis 19, 2508, 2013.

53. Afshari, N.A., Li, Y.J., Pericak-Vance, M.A., Gregory, S., and Klintworth, G.K. Genome-wide linkage scan in Fuchs endothelial corneal dystrophy. Invest Ophthalmol Vis Sci 50, 1093, 2009.

54. Hemadevi, B., Srinivasan, M., Arunkumar, J., Prajna, N.V., and Sundaresan, P. Genetic analysis of patients with Fuchs endothelial corneal dystrophy in India. BMC Ophthalmol 10, 3, 2010.

55. Kuot, A., Hewitt, A.W., Griggs, K., Klebe, S., Mills, R., Jhanji, V., et al. Association of TCF4 and CLU polymorphisms with Fuchs' endothelial dystrophy and implication of CLU and TGFBI proteins in the disease process. Eur $\mathrm{J}$ Hum Genet 20, 632, 2012.

56. Poulsen, E.T., Dyrlund, T.F., Runager, K., Scavenius, C., Krogager, T.P., Hojrup, P., et al. Proteomics of Fuchs' endothelial corneal dystrophy support that the extracellular matrix of Descemet's membrane is disordered. J Proteome Res 13, 4659, 2014.

57. Chen, J., Maeda, T., Sekiguchi, K., and Sheppard, D. Distinct structural requirements for interaction of the integrins alpha 5 beta 1 , alpha $\mathrm{v}$ beta 5 , and alpha $\mathrm{v}$ beta 6 with the central cell binding domain in fibronectin. Cell Adhes Commun 4, 237, 1996.

Address correspondence to: Stéphanie Proulx, PhD Centre de Recherche du CHU de Québec-Université Laval Axe Médecine Régénératrice

Hôpital du Saint-Sacrement 1050 chemin Sainte-Foy Québec G1S $4 L 8$

$Q C$

Canada

E-mail: stephanie.proulx@fmed.ulaval.ca

Received: March 16, 2017

Accepted: July 14, 2017

Online Publication Date: September 28, 2017 